\title{
MECHANISMS AND STRATEGIC PRIORITIES OF STATE FLIGHT SAFETY MANAGEMENT
}

\author{
Ivan Korobka ${ }^{1}$ \\ ${ }^{1}$ postgraguate student, Department of Civil Service, Administration and Training under International \\ Projects, Institute of Public Administration in the Sphere of Civil Protection, e-mail: jonbox@i.ua, \\ ORCID: https://orcid.org/0000-0002-5310-4917
}

\begin{abstract}
The article addresses an urgent problem related to determining the priorities of public management and administration of a safe component of the activity of state and civil aviation in general and aviation of the State Emergency Service of Ukraine in particular against the background of the dynamics of coordination of flights of all types of aviation in the airspace of responsibility of Ukraine.

The Ministry of Defence of Ukraine is the authorized central body of executive power for regulating the activities of state aviation, including the security context. The mechanism of realization of the state policy of Ukraine in the field of aviation activity of all types of aviation is the Authority for Regulation of Activities of State Aviation. This Authority is entrusted with a fairly wide range of powers and tasks. The regulation of these powers and tasks is carried out by administering the entire spectrum of state aviation activities for the intended purpose, and in a security context - strict adherence to the statutory indicators of acceptable risk of flight operations.
\end{abstract}

Overall, flight safety management is based on a systematic approach to identifying and eliminating sources of danger and controlling risks to minimize human, material, financial, environmental and social losses. But in the security context, no significant changes in the system of state regulation of state aviation activity have taken place, traditional approaches that were in place until Ukraine gained its independence still remain. The basis for defining a set of security measures on the basis of a unified approach to aviation activity management still retains a retroactive approach, the essence of which lies in the administrative response and determination of mechanisms of state influence on its state, which obviously leads to a decrease in the effectiveness of state supervision of flight safety of all aviation entities. It is obvious that all existing basic flight safety management concepts are focused on implementing measures after an aviation accident has occurred. Thus, there is no preventive, predictive approach.

The introduction of a modern approach to flight safety management requires the development of new regulations and the improvement of state policy on regulation of state aviation activities. The basis for the formulation of such a policy should be the prognostic assessment of tasks that can be assigned to state aviation at one time or another, the conditions for their implementation (state of emergency, emergency situation, martial law) and, of course, the human factor.

In this context, the author aims to determine the basic concepts, innovative mechanisms and strategic priorities of state aviation safety management based on proactive technologies within the tasks assigned to the aviation of the State Emergency Service of Ukraine (SES).

Keywords: flight safety, state aviation, public management and administration.

JEL Classification: H10, H56

Formulas: 0; fig.: 0; tabl.: 0; bibl.: 20.

Introduction. State aviation safety policy, as a component of national security, has always been the focus of attention, the basic concepts, mechanisms of public administration and strategic priorities of which are clearly reflected in the two State Flight Safety Management Programmes [1, 2]. In this context, the 
state programme is defined as the main mechanism of public administration, the essence of which is to comprehensively define interrelated regulatory acts and measures aimed at improving the level of flight safety.

The Ministry of Defence of Ukraine is the authorized central body of executive power for regulating the activities of state aviation, including the security context. To implement the state policy in the field of state aviation of Ukraine for execution of the joint directive of the Ministry of Defence and the General Staff of the Armed Forces of Ukraine dated 01.07.2013 №D-332/1/02, the Authority for Regulation of Activities of State Aviation of Ukraine (Authority) was created. The Authority, as a mechanism for public administration of state aviation, is entrusted with a rather wide range of powers and tasks [3]:

- exercising the powers of the central executive authority in the field of state aviation;

- participation in the development of draft laws of Ukraine, acts of the President of Ukraine and the Cabinet of Ministers of Ukraine, including issues on flight safety;

- development and implementation of legal acts on regulation of state aviation activities;

- generalization of the practice of applying the legislation on regulation of state aviation activities;

- participation in the organization and conducting state and other tests of aviation equipment samples, search and rescue facilities and facilities for ground based flight support;

- participation in the organization of adoption, the supply of aviation equipment, search and rescue facilities and facilities for ground based flight support;

- participation in the development of technical regulations and the implementation of the technical regulation function in the field of aviation technology, search and rescue facilities and facilities for ground based flight support;

- development, implementation of rules and procedures for the organization, execution and maintenance of aircraft flights;

- organization of the development and implementation of rules for granting (cancelling) addresses of aircraft to state aircraft of Ukraine;

- organization of the development and implementation of the procedure of certification of state aircraft (termination of the certificate), performance of a complex of works related to the verification (control) of the airworthiness of state aircraft for compliance with the requirements of normative documents on the issues of operation and repair of aircraft;

- organization of the development and implementation of the procedure for admission to operation of airfields, runways of state aviation;

- registration and admission to operation of airfields and permanent runways of state aviation, keeping their register; 
- organization and provision of issuance of the Certificate on the admission to operation of an airfield or a permanent runway of state aviation of Ukraine (suspension or cancellation of its validity), which gives its owner the right to operate them;

- keeping a register of temporary registration of aircraft belonging to military equipment (experimental, property of the aviation industry of Ukraine, foreign customers which are being repaired (modernized) in Ukraine);

- organization, development and implementation of rules for approval of organizations for technical maintenance and repair of aviation equipment of state aviation;

- coordinating the interaction of aviation entities in testing and commissioning of new types of aircraft intended for use in state aviation;

- organizing and exercising control over the compliance of aviation entities with the requirements of regulatory legal acts in the field of state aviation;

- keeping the Register of state aviation personnel;

- organization, development and implementation of qualification requirements, procedures of validation, certification, training, retraining and professional development of aviation personnel of state aviation;

- organization, development and implementation of rules for the approval of organizations which train aviation personnel;

- organization, development and implementation of uniform requirements for the admission of aerodrome-technical, radio-technical means, conducting aviation search and rescue and search and rescue support for aircraft in state aviation;

- control over the dissemination of the necessary information to the entities of aviation activity of the state aviation regarding the organization of execution and provision of flights.

All the above-mentioned tasks form the basic paradigm for ensuring the safety of state aviation of Ukraine. The regulation of these tasks is carried out by administering the entire spectrum of state aviation activities for the intended purpose, and in a security context - strict adherence to the statutory indicators of acceptable risk of flight operations.

Overall, flight safety management is based on a systematic approach to identifying and eliminating sources of danger and controlling risks to minimize human, material, financial, environmental and social losses. But in the security context, no significant changes in the system of state regulation of state aviation activity have taken place, traditional approaches that were in place until Ukraine gained its independence still remain. Flight safety management system is defined as a set of measures to apply a unified approach to optimizing the organizational structure, allocation of responsibilities between public authorities and aviation entities, policy definition and operational procedures for ensuring safety of flights.

The basis of this systematic approach and determination of a set of security measures on the basis of a unified approach to aviation activity management still 
retains a retroactive approach, the essence of which is the administrative response and determination of mechanisms of state influence on its state, which obviously leads to a decrease in the effectiveness of state oversight of the safety of all aviation entities.

A detailed study of the current mechanisms of the state flight safety management at the present stage of operation of the aviation system makes it possible to distinguish the following four retroactive basic concepts $[4,5]$ :

- the investigation of an aviation accident on the multi-vector principle;

- the organization of the investigation is based on a planned approach;

- the work of the commission of inquiry is based on the principle of impartiality;

- the investigation is conducted on the principle of openness.

From the above it is obvious that all of the above-mentioned concepts are focused on implementing measures after an aviation accident has taken place. That is, there is no preventive, predictive approach.

The introduction of a modern approach to flight safety management requires the development of new regulations and the improvement of state policy on regulation of state aviation activities. The basis for the formulation of such a policy should be the prognostic assessment of tasks that can be assigned to state aviation at one time or another, the conditions for their implementation (state of emergency, emergency situation, martial law) and, of course, the human factor.

Literature review. A lot of fundamental and applied researches are devoted to theoretical problems of both organizational and legal support of management of activity of state aviation as a special sphere of public management and administration, which was reflected in the Air Code of Ukraine, adopted on May 19, 2011.

According to this document, the main purpose of state aviation using state aircraft is to ensure national security and defence of the state and protection of its population (p. 4, page 4) [6]. The target setting and the range of entities of state aviation, which have legally established ways to achieve it, in theoretical and practical perception associate state aviation with military. However, state aviation also includes aviation military formations formed in accordance with the laws of Ukraine of the National Guard, the National Police, the State Emergency Service of Ukraine and the State Border Guard Service [6]. When considering the problem of flight safety as a single object of public and administrative influence in the context of multi-departmental subordination, it is important to clarify the limits of this influence on the status of the designated object by each of the above-mentioned central executive authorities.

Much research and publication of their results have been devoted to the search for mechanisms of coordinated public and administrative management for the safe execution of flights by aircraft assigned to them under acceptable risk conditions. A study of these publications shows that most domestic researchers agree that proactive methods of assessing flight risks under 
appropriate conditions should be based on this. The new approach, based on the use of pro-active methods in the process of collecting and analysing typical risk factors, served as a justification for the further movement to create an effective flight safety management mechanism, which was reflected in the relevant regulatory documents [7-12].

Flight safety is a dynamic feature of the aviation system, but if proactively identified risk factors are reasonably controlled, flight safety can be managed. In contrast to civil aviation, risk is an integral by-product of state aviation activity. Therefore, risk management for state aviation is a key function of effective flight safety management [9]. However, the achievement of the desired efficiency, as noted by Y.V. Sikirda, B.V. Zubkov, V.L. Shevchenko is possible only if the process of flight safety management encompasses all norms, rules and procedures, which are envisaged by national laws and regulations as well as international standards [10-12]. In the works of the leading foreign scientists B. Lundvall, S. Metcalfe, R. Nelson, D. North, P. Romer, K. Freeman, the proactive approach is classified as innovative, which embodies the most up-todate understanding of the prognostic process of the functioning of any system, including the security context. This reflects the important changes in the conditions and content of innovation activities that have taken place in the last decade, and research based on the concept of innovation system can create a fruitful basis for the development of technological and regulatory policy in the field of state aviation safety management [13-18].

Aims. To determine the basic concepts, innovative mechanisms and strategic priorities of public aviation safety management on the basis of proactive technologies within the tasks assigned to aviation of the State Emergency Service of Ukraine (SES).

Object of study: mechanisms and infrastructure of state aviation safety management. Subject of study. Innovative technologies for the development of the operation of the SES aviation flight safety management system based on the introduction of pro-active risk management methods and methods for identifying threats, predicting their development and the nature of the impact on flight performance.

Methods. Improvement of the state aviation management system at the SES in case of an emergency in the context of the coordination of civil and state aviation activities. Implementation of a unified algorithm for the determination of unacceptable risk prevention measures, which could lead to catastrophic consequences into the safety management system for all state aviation entities.

Results. One of the most important issues for ensuring the safety of flights is to establish and improve the mechanism for coordinating the activities of aviation of the SES involved in emergency response with civil and state aviation. The international standards set out in paragraphs 2.15 and 2.16 of Chapter 2, Annex 11 to the Chicago Convention on Air Traffic Services define the procedure for coordinating actions between military authorities and air 
traffic services (ATS), as well as coordinating activities that are potentially dangerous to civil aircraft.

The main national mechanism for the coordination of aviation activity is the Air Code of Ukraine [6], which structurally divides the airspace of responsibility of Ukraine into areas, zones and routes for aviation activities. The whole system of coordination of joint activities of users of national airspace includes the following structural elements:

- 1 upper airspace flight information region (UIR KYIV);

- 4 regions of flight information (FIR Kharkiv, FIR Kyiv, FIR Lviv, FIR Odesa);

- dispatch areas and zones (UTA, CTA, TMA, CTR) in which air traffic services are provided by the bodies of air traffic services (ATS);

- military ATCA/MILTMA, ATCZ/MILCTR in which air traffic control is carried out by departmental air traffic control bodies (ATC);

- aerodrome flight information zones (AFIZ) -installed to provide flight information and emergency services at AFIS airfields;

- aerodrome traffic zones (ATZ) usually installed for runways;

- routes (ATS), including specially designated routes for crossing the state border;

- free route airspace (FRA);

- prohibited areas $(P)$, restricted areas ${ }^{\circledR}$, dangerous areas (D) - established in areas where flights are prohibited or restricted;

- training areas (T) which have the status of temporarily separated areas (TSA) or temporary reserved areas (TRA);

- areas with a special regime of airspace use - installed along the state border of Ukraine and around the prohibited areas $(\mathrm{P})$.

Within the structure of the SES, the coordination of search and rescue (SAR) aircraft flights are relied on the Main Aviation Search and Rescue Coordination Centre (MASRCC), which in its activity is guided by international, state and departmental regulatory documents governing the interaction with civilian and military elements of air traffic control.

Obviously, the reliable functioning of such a complicated system is a highly complex mechanism for coordinating the joint activity of all airspace entities, and in case of an emergency, the elimination of which involves the search and rescue (SAR) aircraft of the SES, it significantly affects the efficiency, effectiveness and safety of performing the tasks related to emergency response.

Obviously, such a structure for regulating flights, especially in case of an emergency, can hardly be considered rational. Perhaps it is for these reasons that on October 4, 2001, over the Black Sea, during the missile launches at the joint Ukrainian-Russian exercises of anti-aircraft missile troops, the Tu-154 plane was shot down, 66 passengers were killed. For the same reasons, on 17 July 2014, a Boeing 777 aircraft was shot down in the course of Russian armed aggression in eastern Ukraine by the Buk air defence missile, killing 298 people. 
On January 9, 2020, a Boeing 737 passenger plane was shot down in Iran by two rockets of the Thor anti-aircraft missile system. 176 people were aboard, all of them killed.

All these aviation disasters could not have happened if at least one structural element of such a complex flight coordination system, regardless of its level and status, would have predicted a possible scenario for the development of an aviation situation in obviously dangerous conditions. Therefore, focusing on the above state of affairs, the Decree of the Cabinet of Ministers of Ukraine of December 6, 2017 No. 954, On Approval of the Regulations on the Use of Airspace in Ukraine and the rules of Use of the Airspace of Ukraine, approved by the joint order of the State Aviation Service of Ukraine and the Ministry of Defence of Ukraine dated May 11, 2018 No. 430/210, registered in the Ministry of Justice of Ukraine on September 14, 2018 under No. 1056/32508, were put into effect $[19,20]$.

The results of an analysis of the causes of aviation accidents and incidents over the last ten years indicate that approximately 80 per cent of such accidents and incidents have occurred due to misconduct and violations by aircraft crews of the rules of aircraft operation, as well as by the personnel of the air traffic control (human factor). At the same time, the number of incidents due to aircraft failure during flight has increased. Much of the state aviation fleet is technically and physically obsolete.

Conclusions. Thus, a study of the state of aviation accidents that have taken place in recent years shows that there are problems in the functioning of state aviation, the solution of which will significantly improve the security situation of aviation in solving its assigned tasks. Obviously, this is a matter of operation, repair of aircraft, maintenance of airfield infrastructure, training of aviation personnel, a number of social issues that are the subject of study and development of appropriate proposals for decision-making at both departmental and state levels.

\section{References:}

1. Order of the Cabinet of Ministers of Ukraine dated March 5, 2008 № 506-p. On Approval of the Concept of the State Flight Safety Target Programme for the period up to 2020. URL: http://zakon.rada.gov.ua/laws/show/273-2009-\%D1\%80

2. Order of the Cabinet of Ministers of Ukraine dated October 30, 2013 № 944. On Approval of the Concept of the State Flight Safety Target Programme for the period up to 2023. URL: https://zakon.rada.gov.ua/laws/show/944-2013-\%D0\%BF

3. Order of the Ministry of Defence of Ukraine dated September 11, 2013 No. 605 On Approval of the Regulation on Authority for Regulation of Activities of State Aviation of Ukraine. URL: http://www.mil.gov.ua/content/yrdday/605_11092013.pdf

4. Order of the Minister of Defence of Ukraine dated 19.05.2010 No. 256 On Approval of the Rules of Investigation of Aviation Accidents and Incidents in Aviation of the Armed Forces of Ukraine. URL: https://zakon.rada.gov.ua/laws/show/z0386-10

5. Safety Management Manual (SMM) / Doc. ICAO 9859-AN 474. - 3rd ed. - Canada, Montreal: ICAO, 2013. - $300 \mathrm{p}$.

6. The Air Code of Ukraine dated May 19, 2011 No. 3393-VI // Bulletin of the Verkhovna Rada of Ukraine. 2011. № 48-49. Art. 536.

7. Normal Operations Safety Survey (NOSS) / Doc. ICAO 9910- AN 473. - 1st ed. - Canada, Montreal: ICAO, 2008. - 85 p. 
8. Sikirda Yu. V. Importance of risk management in air traffic control / Yu.V. Sikirda, D.O. // Tkachenko Navigation and Traffic Management Issues: All-Ukrainian. Research Practice Conf., Kyiv, November 23-25, 2015: Abstracts. - K.: National Aviation University, 2015. - P. 38.

9. Korobka I. N. Innovative approaches to the flight safety management of the aviation of the state emergency service of Ukraine. Public management: collection. - No. 5 (20). - December 2019. - Kyiv: SE "Publishing House" Personal", 2019. p.142-153

10.Sikirda Yu.V. Estimation of the degree of danger of organizational factors in air traffic management / Yu.V. Sikirda, D.O. Tkachenko // Management of high-speed moving objects and training of operators of complex systems: V Intern. Research Practice Conf., Kirovograd, November 24-25, 2016: materials of Conf. - Kirovograd: Kirovograd Flight Academy of the National Aviation University, 2016. - P. 116-117.

11.Zubkov B.V. Theoretical bases of flight safety. - Moscow: Moscow State Technical University, 1987.

12.Shevchenko V.L. Methodological bases of formation and development of innovative system of safety of state aviation flights. Scientific Bulletin: Civil Protection and Fire Safety № 1 (3) 2017. P. 28-33. URL: file:///C:/Users/Lenovo/Downloads/sbcpfs_2017_1_6.pdf

13.Lundvall B-A. National Innovation Systems: Towards a Theory of Innovation and Interactive Learning/ B-A. Lundvall. - London, Printer, 1992. - 317 p.

14.Metcalfe S. The Economic Foundations of Technology Policy: Equilibrium and Evolutionary Perspectives / S. Metcalfe// Handbook of the Economics of Innovation and Technological Change. Oxford (UK)/Cambridge (US): Blackwell Publishers, 1995. - P. 409-512.

15.Nelson R. National Innovation Systems. A Comparative Analysis/ R. Nelson. - NewYork/Oxford, Oxford University Press, 1993. - 560 p.

16.16. North D. Institutes, institutional changes and economic performance / D. North; / Trans. from English by A.N. Nesterenko, foreword and scientific editing by B.Z. Milner. - Moscow: Foundation of Economic Books "Beginnings", 1997. - 180 p.

17.Romer P.M. Endogenous technological change / P.M.Romer // Journal of Political Economy. 1990, October. - V. 98. - № 5. - P. 71-102.

18. Freeman C. The National System of Innovation in Historical Perspective // Cambridge Journal of Economics. - 1995. - № 19 (1), February. - P. 5-24.

19.Decree of the Cabinet of Ministers of Ukraine of December 6, 2017 No. 954 On Approval of the Regulations on the Use of Airspace in Ukraine. URL: https://zakon.rada.gov.ua/laws/show/954-2017$\% \mathrm{D} 0 \% \mathrm{BF}$

20.The rules of Use of the Airspace of Ukraine, approved by the joint order of the State Aviation Service of Ukraine and the Ministry of Defence of Ukraine dated May 11, 2018 No. 430/210, registered in the Ministry of Justice of Ukraine on September 14, 2018 under No. 1056/32508

Received: January 23, 2020 